\title{
Methodological approaches to assessing the efficiency of growth poles in the economic space of the region
}

\author{
Natalya Novikova $^{1, *}$, and Alexander Leontiev ${ }^{2}$ \\ ${ }^{1}$ Ural State Economic University of Economics, 8 Marta, 62, 620990 Yekaterinburg, Russian \\ Federation \\ ${ }^{2}$ Administration of the city of Yekaterinburg, Lenin Avenue, 24a, 620014 Yekaterinburg, Russian \\ Federation
}

\begin{abstract}
Due to the global world transformations caused by the spread of the new coronavirus infection, the regional development policy requires a radical rethinking. The world economic community is busy looking for new factors to accelerate economic dynamics. The use of space resources, the advantages of polarized development is the basis for the formation and development of growth poles. However, the problems of assessing the effectiveness of this territorial entity remain poorly developed. The purpose of this article is to propose a methodological basis for assessing the effectiveness of growth poles in the economic space of the region.
\end{abstract}

\section{Introduction}

In connection with the spread of the new coronavirus infection (COVID-19), a decline in the economy is recorded in many countries. Thanks to anti-crisis measures, many governments have minimized the impact of the new coronavirus infection (COVID-19).

Given the new reality, it is necessary to get out of the current crisis situation and find options to improve the economic condition of the state. One of the keys to achieving this goal is the application of the "growth pole" concept.

It should be noted that each researcher interprets the concept of "growth pole" and its components differently. Some scholars have pondered the effectiveness of such a policy in the economy of the state.

Taking into account the above, the authors will try to put forward an approach for assessing the effectiveness of growth poles on the territory of macroregions of the Russian Federation.

\footnotetext{
*Corresponding author: novikova@usue.ru
} 


\section{Theoretical basis of the research}

According to V.F. Lapo "The concentration of production in certain regions at first occurs spontaneously, then it becomes stable, as a result, industrial agglomerations appear, and subsequently, it is difficult to change the trends in the concentration of production" [1].

The French economist F. Perroux believed that the concept of "development pole" or "growth pole" meant "a driving economic unit or a group formed by such units." "A simple or complex unit, company, industry, combination of industries is a driving force when it has side effects on other units with which it is in a relationship" [2].

J. Boudeville, a French economist, understood by the growth pole "a set of expanding industries located in an urban area and contributing to the further development of economic activity in the entire zone of its influence" [3].

According to academician P.A. Minakir "In Russia, a polarization structure of the economic space is also being formed, and in part has already formed, in which urban agglomerations are the poles. More likely an exception than a rule is the translation of economic effects from megalopolises into the surrounding economic and geographic periphery" [4]. The author proves that urban agglomerations generate incentives for development in the periphery to a very small extent, absorbing, but not generating outside flows of population and resources. Urban agglomerations are still playing the role of "black stars", sucking in the population and resources, forming markets within their limits, which leads to an ever stronger curvature of space [4].

In addition, P.A. Minakir believes that "the peculiarity of the Russian space is not just its fragmentation, but the presence of three types of territories (zones): with a high concentration of population and economic activity, with their extremely low concentration and extreme for living and economic activity" [4].

Let us single out especially the Soviet experience of introducing production-territorial complexes (territorial-production complex), which began to be used as a tool for the polarization development of territories in the economic regions of the Soviet Union.

Professor N.N. Kolosovsky considers "production-territorial combination (complex)" as "an interdependent (subordinate) combination of production enterprises and settlements (populated areas) either in a limited territory (local complexes), or on the territory of an economic region or subdistrict (district complexes)" [5] ... The author proves that the complex forms a "core", "hearth", "grid" on the territory of the district, the historical process of which is formed under the direct and successive influence of the productionorganized social factors of the complexes (and all-union social factors external to the district).

In order to develop a methodology for identifying growth poles, it is necessary to mention the methodology for establishing a grid of economic regions, developed by N.N. Kolosovsky, which was as follows [5]:

1. Establishing the initial parameters for the development of production, roughly distributing the task for individual industries throughout the country, determining the main possible bases of these industries (based on data on resources and guided by the economic and geographical location of individual points);

2. Studying of transport links, internal and external;

3. Establishing the main provisions and schemes for the development of the power systems of the regions and, finally, the construction of complete balances - energy, raw materials, transport-material, labor and water ones - for each region and the study of the conditions for obtaining the highest efficiency of the entire system.

Professor M.K. Bandman understood by the territorial-production complex "a planned, proportionally developing set of stably interconnected sectors of the national economy, labor and natural resources, which [6]: 
- $\quad$ is formed and functions with the aim of solving problems of the national economic level of significance,

- concentrated in a limited and compact area,

- ensures efficient use of resources,

- is served by a unified infrastructure system and ensures the creation of the planned living conditions for the population and environmental protection."

A team of scientists led by A. A. Urunov believes that "the economic category of the "development pole" is directly related to such a concept as" points of economic growth "[7].

As a result of their research, it was revealed that "the higher attractiveness of development poles and the propulsive action of growth points is due to the action of a synergistic effect, which manifests itself in the diversification and modernization of enterprises in the compactly located territory of the region." According to scientists, the synergistic effect is defined as an increase in the efficiency of activities as a result of integration between technologically related industries belonging to different sectors of the economy, when new more productive properties arise: benefits from the joint use of the industrial and social infrastructure of the region, an increase in the volume of freight traffic, and expansion of product markets [7].

As part of the study, the authors will apply theoretical and empirical methods to develop an approach to assessing the effectiveness of growth poles in a macroregion.

\section{References}

The analysis of scientific publications carried out by the authors revealed that many researchers have different understandings of the essence of the "growth pole" concept:

- as a group of enterprises (companies) concentrated in a certain territory;

- as a group of innovative (progressive or leading) industries;

- as a city of administrative importance;

- as an urban agglomeration.

The authors understand by the concept of "growth pole" a complex of enterprises concentrated in a certain territory and having a strong impact on the quantitative and qualitative characteristics of the socio-economic development of the region.

A necessary condition for the emergence and further organization of this or that growth pole is the provision of the necessary infrastructure for the effective functioning of enterprises.

In addition, tools of tax reliefs are used, including the reduction of administrative barriers, on the part of the state (region) as a motive for the interest of large enterprises in the presence of one or another pole of growth.

According to the authors, the following classification of growth poles is distinguished, based on their content and purpose [8]:

- clusters;

- an innovative science and technology center (technology parks, science cities, satellite cities, an innovative quarter within a city);

- special economic zones;

- territories of advanced social and economic development;

- industrial parks.

At the moment, in accordance with the official websites of the Ministry of Economic Development of the Russian Federation, the Ministry of Science and Higher Education of the Russian Federation, "Map of Russian Clusters", "Union of Innovative and 
Technological Centers of Russia", "Industrial Parks and Technoparks of Russia", more than 500 growth poles have been formed on the territory of the Russian Federation.

For example, according to the existing economic zoning, the Ural macroregion is outlined by the boundaries of seven subjects of the Russian Federation: Sverdlovsk, Chelyabinsk, Kurgan, Orenburg regions, Perm Krai, the Republics of Bashkortostan and Udmurtia. At the moment, there are more than 60 growth poles in the Ural macroregion.

Taking into account the practical experience of introducing the concept of "growth pole" in the territory of the former Soviet Union and the Russian Federation, the following criteria can be distinguished that determine the appearance of growth poles:

1. historical connection (determinism);

2. spontaneous occurrence;

3. state (regional) policy.

Also, growth poles have the following characteristics:

1. concentration of a huge amount of resources in a certain area (financial, labor, natural, administrative, managerial and others);

2. use of effective and innovative factors of production for increasing the scale of production (intensive economic growth);

3. availability of infrastructure;

4. economic potential of the territory.

Currently, many researchers are trying to develop a methodology for assessing the effectiveness of growth poles. Considering that there are many types of growth poles, as well as subcategories, it is necessary to highlight the key results of the application of the "growth pole" concept on the territory of the Russian Federation.

According to the authors, this assessment of the effectiveness of the application of the concept of "growth pole" will consist of the following stages.

The first stage is to consolidate data on growth poles, for example, on the territory of the Ural macroregion, which were introduced during 5-10 years.

Given the fact that many subjects of the Russian Federation do not publish information on growth poles, it will be necessary to calculate the total number of growth poles on the territory of macroregions. The number of growth poles will be calculated in accordance with the information presented on the official websites of the government executive bodies, scientific and private organizations.

The second stage is to put forward criteria that are related to the indicators of socioeconomic development of the constituent entity of the Russian Federation. According to the authors, it is necessary to highlight the following criteria for calculating the effectiveness of growth poles in the region, which will be the basis for testing this technique (Table 1):

1. economic;

2. the level of income of the population;

3. employment of the population;

4. entrepreneurship;

5. demographic;

6. informational;

7. investment;

8. innovative. 
Table 1. Criteria and indicators for calculating the effectiveness of growth poles in the territory of the Russian Federation

\begin{tabular}{|c|c|}
\hline Criteria & Indicators \\
\hline Economic & $\begin{array}{l}\text { Gross regional product. } \\
\text { Industrial production index. } \\
\text { The volume of shipped goods of own production, work and services performed } \\
\text { by type of economic activity. } \\
\text { Transportation of goods by types of public transport. } \\
\text { Transportation of goods and freight turnover of road transport of organizations } \\
\text { of all types of economic activity. } \\
\text { Turnover of organizations }\end{array}$ \\
\hline $\begin{array}{l}\text { Income of the } \\
\text { population }\end{array}$ & Average monthly nominal wages \\
\hline $\begin{array}{l}\text { Employment of } \\
\text { the population }\end{array}$ & Number of employees of organizations \\
\hline Entrepreneurship & Number of small and medium-sized businesses \\
\hline Demographic & $\begin{array}{l}\text { Population. } \\
\text { Migration increase (decrease) of the population. } \\
\text { Natural increase (decrease) of the population }\end{array}$ \\
\hline IT & $\begin{array}{l}\text { Number of organizations using global information networks, by type of } \\
\text { economic activity }\end{array}$ \\
\hline Investment & Investment in fixed assets \\
\hline Innovative & $\begin{array}{l}\text { Research and development costs. } \\
\text { Innovative activity of organizations for certain types of economic activity. } \\
\text { The volume of innovative goods, works and services for certain types of } \\
\text { economic activity. } \\
\text { The share of innovative products in the total volume of goods, works and } \\
\text { services shipped by industrial enterprises (at the end of the period) }\end{array}$ \\
\hline
\end{tabular}

The third stage is to build a model that will reflect the dependence of the values of indicators of socio-economic development of the territory (subject of the Russian Federation) on the number of formed growth poles. Statistical data of the subjects of the Russian Federation for 5-10 years will be presented according to the information of the government executive bodies. After constructing the assessment, it will be necessary to describe the results obtained and assess them.

In accordance with the hypothesis, the values of indicators of socio-economic development will improve due to the introduction of growth poles and their economic return.

\section{Conclusions}

The "growth pole" concept is one of the instruments of regional policy to achieve economic growth. Taking into account the foreign experience of introducing growth poles, it is necessary to rethink the effectiveness of this concept, identify problem points and subsequently develop proposals for improving the practice of introducing growth poles in a particular territory of the Russian Federation.

Therefore, an important step is to develop an approach to assessing the effectiveness of the "growth pole" concept in the macroregions of the Russian Federation.

\section{Acknowledgments}

The article was carried out with the financial support of the RFBR grant "Incremental approach to the formation and implementation of strategies for the socio-economic 
development of regions of various hierarchical levels of the Russian Federation: uniform rules for strategizing" (project No. 20-010-00824).

\section{References}

1. V.F. Lapo, Izvestia of the Irkutsk State Economic Academy, 3-4, 34 (2005)

2. F. Perroux, Paris: Presses Universitaires de France, 598 (1961)

3. J. Boudeville, Edinburg: Edinburgh U.P., 192 (1966)

4. P. A. Minakir, Strategic Deadlocks, Economy of the Region, 15(4) (2019)

5. N.N. Kolosovsky, The Theory of Economic Reinformation, 334 (1969)

6. M.K. Bandman, Selected Works and the Continuation of the Started, 448 (2014)

7. M.M. Avezova, A.A. Urunov, M. A. Nasimova, Methodological and practical aspects of identifying development poles and growth points in the regional economy, 161 (2020)

8. N. Novikova, A. Leontiev, SHS Web Conf. 3rd International Scientific Conference on New Industrialization and Digitalization (NID 2020), 93, 6 (2021) 